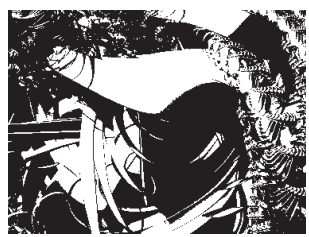

\title{
TIPOVI LIKA ISELJENIKA U NOVIJOJ HRVATSKOJ KNJIŽEVNOSTI
}

Cvjetko MILANJA

Institut društvenih znanosti lvo Pilar, Zagreb

UDK: $821.163 .42 .09^{\prime \prime} 18 / 19^{\prime \prime}$

314.723:82

Izvorni znanstveni rad

Primljeno: 6. 4. 2010.

U radu se skicira moguća tipologija lika iseljenika u hrvatskoj književnosti 19. i 20. stoljeća. Kako gotovo ne postoje slični radovi u hrvatskoj književnoj historiografiji, to se metodološki upozorava na dvije razine i dvije odvojene teme - tretiranje navedene teme domicilne i egzilne literature. Načelno se razlikuje tip lika ekonomske provenijencije - zgrtalački mentalitet, uz nostalgičara doma - te lik intelektualca umjetnika koji odlazi van iz kulturnih potreba i konačno lik političko-ideološkog utemeljenja, kojim se više bavila egzilna literatura.

Ključne riječi: politički iseljenik, ekonomsko-zgrtalački tip, zajednica, pojedinac, intelektualac, umjetnik, književnost

$\triangle \quad$ Cvjetko Milanja, Institut društvenih znanosti Ivo Pilar, Marulićev trg 19/1, p. p. 277, 10001 Zagreb, Hrvatska. E-mail: Cvjetko.Milanja@pilar.hr

\section{UVOD}

Tema "tipova lika iseljenika" u novijoj hrvatskoj književnosti do sada je, koliko mi je poznato, u kulturološko-sinteznom smislu, uglavnom neobrađeno područje istraživanja, pa se na neku relevantnu literaturu, i glede metode i glede tipologije, a još više kao procesa kulturne modernizacije, ne možemo pozivati. Dakako da se opazaka nužno mora naći u stručnoj literaturi koja se bavila određenim piscem koji je u svojem nekom djelu baratao i tim likom, kao primjerice Vojnović (usp. Suvin, 1977.), ili Tucić (usp. Hećimović, 1976.), ili Kranjčević (usp. Jelčić, 1984.), ili Krleža (usp. Lasić, 1987., Žmegač, 1986.), pa će, dakle, i kritički napisi o njegovim djelima, u kojima se manipulira likom ise- 
DRUŠ. ISTRAŽ. ZAGREB GOD. 20 (2011)

BR. $3(113)$

STR. $861-876$

MILANJA, C. TIPOVI LIKA ISELJENIKA... ljenika, nužno uključivati i navedenu temu, što će se u ovim našim objekcijama podrazumijevati ili na te radnje referirati. No u ovom uvodnom dijelu nužne se neke napomene, kao samopodrazumijevajući horizont problematiziranja.

Naime, kada se upuštamo u metodologijsku skicu naznačene teme, nužno je upozoriti da je potrebno razlikovati ne samo dvije razine problema nego gotovo dvije odvojene teme. Jedna uzima u obzor motrenja način kako domicilna hrvatska književnost obrađuje temu iseljenika, odnosno nekih predstavnika iseljene Hrvatske, pa se s tim u vezi može načiniti mala tipologija i glede društvenoga statusa (klase), odnosa prema obitelji kao elementarnoj stanici društva, i svijesti sebstva, što znači ontološkoga statusa, a posve je druga i različita tema kako se iseljena, druga Hrvatska, odnosno njezina egzilna literatura "iznutra" odnosila prema iseljenoj "supstanciji", i/ili kako je ona tretirala "prvu" Hrvatsku, njezinu, posebno političku, kulturnu, a i književnu stvarnost, kako je izgledala njezina kultura i književnost, posebno ona pisana hrvatskim jezikom (primjerice u "Hrvatskoj reviji" - od Nikolića i Bonifačića do Marune). Pri tomu bi bilo nužno problematizirati razinu i instanciju hrvatskoga jezika, koja je njima služila kao metonimija Hrvatske i hrvatstva, jer je jezik za njih u doslovnom smislu bio, humboltovski rečeno, istinski zavičaj, a hajdegerovski pak kazano "kuća bitka" (zbog kojih razloga je Vida počinio samoubojstvo), potom semantički (motivsko-tematski) sloj, posebno prirodni i krajolični motivi, jer su i oni mogli figurirati kao politička, ali i "kampanilistička", transplantacija Hrvatske, i jamačno stilskoparadigmatska, poetička i estetička njezina realizacija, kao umjetnička uvjerljivost, da bi se detektirala i opisala njezina suvremenost ili zastarjelost $\mathrm{s}$ obzirom na ideju književnosti. Ako je jezik za njih bio legitimacijsko-identitetsko određenje biti, književnost im je služila kao sentimentna i nostalgična gesta utjehe, neka vrsta "kućnoga" intimnoga herbarija, koji je doduše imao ambicije reprezentacije "književne druge Hrvatske", što je "pozitivistički" i bio, ali je estetički u većini slučajeva, uz male iznimke (Maruna), uglavnom bio insuficijentan.

Treća uvodna napomena odnosila bi se na društveno-političku i ekonomsku situaciju u Hrvatskoj u tri različita modaliteta kolonijalizacije - austrougarske, prve te druge Jugoslavije. Ta je kolonijalizacija rasla progresijski, i kad je bilo u pitanju novčano izdvajanje Hrvatske, i kad su bile u pitanju slobode, naročito uvjetovane ideološkim (partijskim ili državno-režimskim) razlozima, a i kad je bila u pitanju kulturna sloboda stvaranja u skladu s europskim i svjetskim idejama umjetnosti i njihovim stilskim raznolikostima, što dokazuju različiti tipovi cenzura od ideološko-partijskih do autocenzura samih pisaca. 
DRUŠ. ISTRAŽ. ZAGREB GOD. 20 (2011), BR. $3(113)$

STR. $861-876$

MILANJA, C.: TIPOVI LIKA ISELJENIKA...
Iz toga jasno proizlazi, četvrto, da se načelno i makrotipološki "lik iseljenika" može grupirati ili s obzirom na ekonomsko stanje, pa tada govorimo o ekonomskoj emigraciji, kakve nakon planirana pomora vinogradarstva u 19. stoljeću ima sve više u sva tri politička poretka, i u tom je modelu tipološki spektar najrazličitiji u rasponu od propaloga tipa do kapitalista. Drugi bi tip bio provociran političkim stanjem, pa govorimo o političkoj emigraciji, kakve je također bilo u sva tri politička sustava, od pojedinačnih "privatnih" sudbina do njihova refleksa u različitim tipovima diskurzivna zapisa, od memoara do fikcionalne tvorbe, kao primjerice Cesarčev roman Bjegunci, koji tematizira međuratnu političku emigraciju u Pragu. Međutim, taj se tip propulzivnije razvio naročito u drugoj Jugoslaviji nakon 1945., od D. Žanka i B. Radice do V. Vide i B. Marune, a njega bi bilo umjesno problematizirati unutar teme iseljene Hrvatske, a u uskoj vezi s djelovanjem časopisa "Hrvatska revija", i dakako drugih relevantnih listova i publikacija, to više što je to pogled "iznutra", iz druge, iseljene Hrvatske. No to su privatno-javne sudbine čija se memoarska proza (primjerice Štajner) može koristiti dakako za upoznavanje relevantnosti "prirode stvari", ali u užem smislu riječi ne ulazi u ovu našu tipologiju, nego u društvenu sliku zbilje "obiju" Hrvatska. Možda izgleda malo paradoksalno da hrvatska domicilna književnost u vremenu socijalizma i komunističkoga totalitarizma nije značajnije tematizirala "lik političkog iseljenika", pa to odsuće kao književna diskurzivna nijemost govori koliko o represiji još i više o nemoći hrvatske književnosti da se s tim uhvati ukoštac. Razlozi mogu biti od otvorene ideološko-partijske cenzure do autocenzure i sigurne zavjetrine "arkadijskog mira", udaljenih od mogućega prijestupa. Treći je tip kulturni "lik iseljenika", koga se ne bi moglo u strogom smislu tretirati kao emigranta, nego kao model koji je provociran osobnim potrebama proširivanja kulturnih i umjetničkih spoznaja kao i "vježbanja" vlastitih kreativnih mogućnosti u skladu s novim umjetničkim idejama i praksama. On, naprotiv, $u$ užem smislu nije povezan s prethodnim ni ideološki, ni kulturološki, jer je u prethodnom tip ideja kulture, kao i umjetničkih praksi, navlastito književnosti, kojoj je medij hrvatski jezik, bila tradicionalnija, konzervativnija, stilskoparadigmatski, dakle je kasnila za recentnim umjetničkim idejama i ostvarenjima, jer je prvenstvena briga, načelno, bila "očuvanje" i "konzerviranje" hrvatskoga jezika i kulturna stanja kakav su odnijeli sa sobom, što je evidentno na književnom korpusu najrelevantnije egzilne "Hrvatske revije". U tima trima tipovima iseljenika - ekonomskog, političkog, kulturnog (i znanstvenog) - načelno bi se iscrpila moguća tipologija, jer sve ostalo bilo bi ili putopisno landranje po svijetu, pa bi to bio bedekerski tip, kakva u hrvatskoj književnosti ima obilato (od Ma- 
DRUŠ. ISTRAŽ. ZAGREB GOD. 20 (2011), BR. 3 (113),

STR. $861-876$

MILANJA, C. TIPOVI LIKA ISELJENIKA.. tije Mažuranića naovamo), bonvivansko, pa bi dakle bila riječ o svojevrsnom plejbojskom tipu, kakvo je dijelom bilo i Begovićevo (Liddy), ili pak ratnozarobljeničko, pa bi se radilo o tipu ratne žrtve, kakav je opet Begovićev glavni muški junak (Marko) u drami Bez tré́ega, ili je pak riječ o memoaristici, pa bi bila riječ uglavnom o ideološko-uzničkom tipu, kakva su sibirska sjećanja K. Štajnera.

\section{TIP LIKA ISELJENIKA KAO NOSTALGIČARA DOMA}

U ovom napisu, hipimice, usredotočit ćemo se na prvu temu, to jest kako je domicilna hrvatska književnost manipulirala likom iseljenika, uzimajući pritom dakako paradigmatskije primjere, a korpus na kojemu će se to oprimjeriti jest vrijeme 19 . i 20. stoljeća.

Počeo je to već Preradović poznatom pjesmom o putniku, pri čemu je metaforu putnika prepoznati kao neuspjela tražitelja bolje sreće u prostoru izvandomovinskom, pa je priziv i komentar lirskoga kazivača, u obraćanju putniku, jasno iskazivanje zabrinutosti i blagoga patronatstva nad osjećajnim, sentimentnim i domoljubnim gestama koje u njemu valja probuditi kako bi spoznao vrijednost i nezamjenjivost domovine majke, to jest roditeljice. U tom se nacrtu inozemstvo nadaje kao tuđost koja satire autentičnost i "domaćost", pa je to put u posvemašnju alijenaciju - sebstva, pojedinačnosti, kolektivnosti, domovinstva.

Drugi je primjer Kranjčevićev Iseljenik, koji barata drugačijim tipom "lika iseljenika", pripravnika i tek može se reći vježbenika za daleki "faram Brazila" ili rudarsko okno. On odlazi u svijet prignječen ekonomskim razlozima, pa daleku zemlju projicira kao nekakav željkovani Eldorado. On, kao onaj raniji (Preradovićev), ne osjeća "novu stvarnost" kao uskratu sebstva, nego nekakvu tihu nadu, barem kad je riječ o materijalnom statusu. Neposredno je to naviješteno brodom koji prolazi pokraj njegova i veseljem iseljeničkih radnika koji se vraćaju kući. To veselje ne valja shvatiti samo kao sreću zbog dolaska domu nego i kao rješenje ekonomskoga statusa, pa se onaj koji je zbrinutiji i novčano neovisniji kući vraća veseliji, jer je ostvario jednu od svojih projekcija. Međutim, Kranjčevićev je iseljenik u bipolarnoj poziciji već na odlasku iz Hrvatske. On, naime, stoji sam, kao pojedinac, izdvojen iz mase i u toj samotnoj, individualnoj poziciji prisjećajnim radnjama priziva svoju obitelj suprugu i njezine priče djeci, priče o Marinoj kruni. To je važno u dvostrukom smislu; na jednoj je to razini resentiment obiteljske idile i život (oca) žrtvom posvećena obitelji kao "svom svijetu", što će vjerojatno u tuđem svijetu stvarati psihološke poteškoće u adaptaciji, a na drugoj razini to je san o blagu, zlatu, Marinoj kruni, što ju je - prema narodnoj pjesmi, koju Kranjčević intertekstno priziva - ugrabio Črni Moro, pa je analogno pretpostaviti da će i "naš čovo" ostati prikraćen za svoju projekciju - novčano zbrinjavanje svoje obitelji. Već je tu Kranjče- 
DRUŠ. ISTRAŽ. ZAGREB GOD. 20 (2011), BR. 3 (113),

STR. $861-876$

MILANJA, C. TIPOVI LIKA ISELJENIKA... vić scenski postavio svoj lik u opoziciji prema masi, što će kasnije Krleža razviti likom Kolumba. Ovdje se lik nadaje ne samo kao ekonomska figura nego i kao antropološki faktor u složenoj etnografsko-porodičnoj seoskoj "idili".

Je li Matošev Iseljenik, koji u podnaslovu nosi žanrovsku oznaku "balada", sličan ranijima ili potonjima? Kako je pjesma posvećena dr. Mili Starčeviću, pretpostaviti je donekle bar neke segmente njezina sadržaja i značenja, bar dakle njezin politički semantički sloj i pravaški svjetonazor. On stoji "u sredini" sasvim određenim idejama. Matoševa ideja lika iseljenika postavlja složenu lepezu problema, jer je on višeslojno određen. On ne odlazi u Ameriku, koju izričito spominje, pa znademo da putuje onamo, radi neposredne materijalne, novčane dobiti, kako bi poboljšao egzistencijalni status, nego zato da plati dugove (porez i kamatarenje), pa su njegovi razlozi za emigriranje posve drugačiji od ranijih i potonjih (u Tucića). Na drugoj je razini pitanje odnosa Hrvatske spram Mađarske/Austrije, pa je indirektno riječ o onodobnoj političkoj zbilji i političkom kolonijalnom statusu Hrvatske, pa dakle i njezine supstancije, koja se kod kuće osjeća kao stranac. Lik je u tom slučaju bezdomovinski, iako ima domovinu činjenicom da ona nije slobodna nego potlačena. Prema tome, već je on u vlastitoj domovini neka vrsta roblja, što će biti i kad ode u inozemstvo, pa već možemo pretpostaviti da mu se status neće promijeniti, iako priželjkuje status robinzonske slobode i mjesta daleko od civilizacije. U igru ulazi i položaj obitelji, supruge i djece. Naime, žena će se vjerojatno podati nekom državnom službeniku, što je dvostruki grijeh: zatiranje obiteljskoga jedinstva i podavanje služitelju strane političke okupacije, pri čemu lik planira osvetu, čime će Ameriku zamijeniti Lepoglavom, što je Tucićev junak i učinio. Ulazi u igru i daljnji segment, a to je, za Matoša sigurno, a i za lik, pitanje slobode. Može li, naime, novi svijet, uz pretpostavke kakve su navedene, ponuditi ostvarenje slobode, što u Hrvatskoj nije postigao, pri čemu se misli na državno-političku slobodu. Lirski kazivač i komentator veli da se sloboda ne može osvojiti nego u vlastitoj zemlji, domovini, jer "sloboda tuđeg kraja" nije istinska sloboda, jer se sloboda ostvaruje tek življenom zavičajnošću, pri čemu Matoš misli na slobodnu Hrvatsku i užezavičajnu, na narod, na tradiciju, genetsku, kulturnu i uželokalnu. Bez tih pretpostavaka pojedinac gubi sebstvo, on je Nitko, kako podvlači Matoš. Tu je pojedinac državnopravna realizacija.

\section{TIP LIKA ISELJENIKA KAO KAPITALISTIČKO-ZGRTALAČKOG}

Kakav je treći tip, model, što nam ga nudi hrvatska književnost 19. stoljeća primjerom Vojnovićeva Nike iz Ekvinocija? To je već primjer liberalističkoga kompradorskog kapitalističkog pro- 
DRUŠ. ISTRAŽ. ZAGREB GOD. 20 (2011) BR. 3 (113),

STR. $861-876$

MILANJA, C. TIPOVI LIKA ISELJENIKA... mesa" žena, s druge strane. Doduše, njega je naznačio već Šenoa komedijom Ljubica upravo likom Ljubice kao zelenaša i kamatara te potrošača mladih muških tjelesa, pa je već tu financijski kapital, sa svojom logikom, unišao u hrvatsku književnost prilično radikalno i otvoreno. Niko, Vojnovićev, otac je izvanbračnoga sina, što znači da je ostavio i prevario djevojku i kao takav je, u skladu s vladajućom kršćanskom etikom, destruktor institucije bračne zajednice (obitelji) kao temelja društva. Odbacuje da naknadno ispravi promašaje i legalizacijom braka rekonstruira i (re)konstituira obitelj i tako naknadno spasi $\mathrm{i}$ ispravi svoje propuste. Naprotiv, on ponovno traži "mlado meso" u skladu sa svojom trgovinskom vrijednosno-potrošnom idejom uopće, pa tako i žene kao kućne domaćice i sobarice. A spram društvenoga korpusa legitimira ga njegova bilježnica smrti; naime, on je običan liferant bijelim robljem za udaljene prekomorske zemlje Južne Amerike i kao takav nadaje se kao onodobna neka vrsta poslovnoga mafijaša, ili modernoga kapitalista, što mu dođe na isto.

Nešto je modificiraniji tip lika u Tucićevu Povratku, koji kao da je ostvario materijalnu neovisnost, jer kući dolazi s brdom novca. No situacija je složena: na prvoj razini, novac nije zarađen, nego je iznuđen (namjernim ranjavanjem osakaćenjem); na drugoj razini umjesto u obiteljsku sreću i željkovanu idilu, on dolazi u opustošenost - žena ga vara s drugim i pače je trudna s njim. I tada nastaje totalno rasulo, a zapravo "poravnanje", i s obzirom na psihološku uvjerljivost, i s obzirom na erotsku rastrošnost, i s obzirom na društvenu projekciju. Dok je za prvo sam kriv jer namjerno podmeće ruku da se na radu ozlijedi i tako iznudi osiguraninu, za drugo je "krivac" prvo njegova projekcija idilične obiteljske hrvatske sreće kako ju je gajila šenoinska paradigma, drugo u odsutnosti tamne osjećaji ionako ugroženi slavonskom formom mentis, a na trećem je mjestu supruga, sa svojom majkom, zapravo predstavnica onodobnoga modernog erotskog trampa, danas bismo rekli sponzoruša. Ta dva primjera ilustriraju rasulo institucije obitelji i zgrtalački mentalitet u modernom kapitalističkom liberalističkom uređenju na prijelazu iz 19. u 20. stoljeće, ilustrirajući tako ujedno i neke od segmenata kulturne modernizacije Hrvatske i njezin "ubrzani" tijek.

Tip amerikanizirana lika, koji želi svoje zamisli i nakane ostvariti pošto-poto, detektirala je hrvatska knjiženost međuraća. Tako primjerice Budak u Ognjištu likom Blaža podastire upravo jedan takav "lik iseljenika", koji vrativši se nastoji Aneru, svoju nevjestu, imati seksualno, čime Budak upućuje na destrukciju ličkoga porodičnoga patrijarhalnoga mita, unoseći element moralne izopačenosti onih aktera koji su zatrovani amerikanizmom, pa se na taj način gospodarska i novčana kapitalistička liberalistička modernizacija ovdje obrće u uništa- 
DRUŠ. ISTRAŽ. ZAGREB GOD. 20 (2011), BR. 3 (113)

STR. $861-876$

MILANJA, C. TIPOVI LIKA ISELJENIKA... vajuću destrukciju. A time se želi upozoriti na dvostruko lice modernoga kapitalističkoga načina života i njime usvojenih ideja, koje se iz moguće pragmatične korisnosti preobrću u načelnu moralnu izopačenost, koja destruira tradicijom strukturiran način očuvanja ognjišta, što je simbolom porodične harmonije, kontinuiteta i uopće porodičnog etosa. Takvih će american-boysa biti u različitim varijantama kasnije, ali će njima svima biti karakteristična još i danas poznata maksima naših primorskih Amerikanaca "koliko si šoldov učini" kao ostvarenja američkoga sna, koji jamačno makijavelističkom logikom zgrtanja isključuje etičku konstantu. Doduše, ta je logika i psihološki razumljiva, jer su likovi u iseljeništvo otišli da se oslobode siromaštva i financijski zbrinu te tako osiguraju bolji standard i veću kupovnu moć kojom bi zadovoljili svoje potrebe. Kako se njihove potrebe nisu kretale i u kulturnom sektoru, jer naprosto nisu niti bili odgojeni niti su imali svijest o zadovoljavanju kulturnih potreba, njihove želje su se iscrpile u boljem materijalnom statusu (kuća opremljena tehničkim pomagalima, automobil) i eventualno popravaka kuće u "starom kraju", ili izgradnja nove kuće kako bi u mirovini uživali blagodati svojega rada. Međutim, usredotočujući se samo na financijski dobitak, oni su umnogome još više osakatili određene tradicijske vrijednosti "staroga kraja", jer su moralne kategorije koje su "prenesene" iz staroga kraja ubrzo nestale silinom moći financijskoga sektora koji im je dao i stvarnu predodžbu o moći da se ima sve što se poželi, a kako su njihove želje bile "skromnije" jer nisu poznavali druge modalitete realizacije moći osim udobna standarda (kuća, automobil, brod), oni su držali da su ostvarili svoj američki san, koji je podrazumijevao da se novcem može sve kupiti, i oni su doista "sve" kupili, a da pritom nisu bili svjesni što su time izgubili. To što je tim likom pisac otvorio i problem erotskoga, nagonskoga, seksualnoga tipa lika, koji se iz razvoja situacije nadaje kao primarni pokretač Blažinih reakcija i radnji, i koji kao da ne može opstojati bez tih zadovoljenja bez obzira na način kako to ostvariti, možemo za tren ostaviti u zagradama, jer to nije bila planirana pripovjedna autorova intencija, iako je on kao "freudovski" tip dakako zanimljiv.

\section{TIP INTELEKTUALCA I UMJETNIKA}

Dio romana hrvatskoga realizma kao svoj glavni lik imao je intelektualca koji se školovao izvan Hrvatske, uglavnom u Beču i Pragu, pa ih se $u$ tom segmentu može problematizirati kao "iseljeničke likove" - dakako ne iz ekonomskih razloga - to više što se nakon povratka u Hrvatsku nisu mogli adaptirati i uglavnom su, uz iznimke, završavali tragično upravo zbog toga što su ostali u "rascjepu" između ponuđenoga europskoga kulturnoga modela koji, izgleda, nisu bezostatno usvojili, i vla- 
DRUŠ. ISTRAŽ. ZAGREB GOD. 20 (2011) BR. $3(113)$

STR. $861-876$

MILANJA, C. TIPOVI LIKA ISELJENIKA... stitoga, domaćega, hrvatskoga, koji nisu bezostatno napustili. Oni su najslojevitiji i najzanimljiviji "likovi iseljenika" i u stanovitom smislu reprezentiraju i legitimiraju kulturnu čežnju Hrvatske, pa su zato u biti i najtragičniji ne samo po sudbini nego i po svijesti o vlastitoj tragičnosti i aporiji. Njih se ugrubo može tipologizirati ili kao one koji su prirodoznanstvene orijentacije, ili kao pravnike, ili pak kao umjetnike. Vraćajući se u Hrvatsku, nastoje uvesti nove privredne, proizvodne tehnologije, kao primjerice Kozarčev Lešić (Mrtvi kapitali). Dok je on glede tehničkog elementa (unapređenje poljoprivrede) tip modernoga ekonomskog tehničkog inženjera, na temeljima Rikarda i Smitha, onodobno relevantnih imena, u društvenom segmentu, pak, u obitelji, on je tradicionalist, dapače patrijarhalni konzervativac i kao takav odnosi se prema vlastitoj supruzi. Na taj je način i on neka vrsta bipolarne osobe, jer sferu ekonomskoga tehničkoga napretka, modernosti, nije uspio prenijeti i na cjelokupni način života, što bi ga u pravom smislu legitimiralo kao čovjeka koji je modernitet trasirao kao način djelatne prakse u svakom smislu riječi.

Prirodne znanosti studira i Novakov Pavao Šegota, po uzoru na Šenoina prijana Lovru, ali dok Lešić stoji čvrsto bar u svojem tehnologijskom segmentu iz kojega prosperitetno djeluje, Novakovi likovi završavaju drugačije. Tomu valja pridodati Tita Dorčića, Amadeja Zlatarića (iz Dva svijeta) i Jurja Stipančića (Posljednji Stipančići), a njima pak Janka Borislavića iz istoimena romana Gjalskoga i Đuru Andrijaševića iz romana Bijeg M. Cihlara Nehajeva. Njih načelno karakterizira dekadentan i destruktivan element, bilo da su promašili profesiju (kao Tito Dorčić po nagovoru roditelja), pa su u biti duboko nesretna bića, ili su se potpuno odnarodili, kao Juraj Stipančić, pa su svojevoljno iskorijenjeni i kao takvi djeluju razarateljski na najbližu, rodbinsku sredinu (sestru, majku), bilo da su faustovski opsjednuti strašću za apsolutnim znanjem koje ne mogu apsolvirati, kao što je to slučaj s Jankom Borislavićem, pa oni predstavljaju, a time i anticipiraju, Foucaultovu epistemološku katastrofu, bilo pak da kao umjetnici propadaju u provincijskim zaturenim hrvatskim prilikama i njezinim malograđanskim formama mentis, kao Amadej Zlatarić ili Đuro Andrijašević, te na kraju polude i čine samoubojstvo. Njih se dadne tumačiti i "na pozadini" onodobnoga političkoga stanja - kolonijalnoga statusa Hrvatske i pravaške (retoričke, a ne djelotvorne) orijentacije gotovo svih realista. No oni taj segment ne osvješćuju (osim u romanu Gjalskoga U noći, koji zato i jest društveno-politički roman), pa ih se ne smije tumačiti kao politička bića, nego se ponajprije sudaraju s provincijskim mentalitetom i vlastitom nemoći da ga prevladaju, kojemu stanju pogoduje dakako i siromaštvo, prouzročeno, uz ino, i političkim stanjem. Tip hamletovsko-šopenhauerovskog umjet- 
DRUŠ. ISTRAŽ. ZAGREB GOD. 20 (2011), BR. 3 (113)

STR. $861-876$

MILANJA, C. TIPOVI LIKA ISELJENIKA... nika koji dospijevaju do vlastite dekadencije, ali ne vajldovskoga modusa, nego tragične sudbine koja ih odvodi u smrt, jednako je činjenica društvene i političke stvarnosti Hrvatske kao i njihove nemoći da transcendiraju takvo stanje nemoći, jer su precijenili svoje mogućnosti, ili pak nemoći jer se ne mogu konstituirati kao subjekti (sebstvo) i u tom smislu akteri scene, koja ih inače destruira. Nisu li to već "nacrti" tipova "lika iseljenika" kao iskorjenjenika koji nisu u punom smislu modernistički osviješteni, pa je nemoć adaptacije jednako posljedica društveno-političkoga stanja koliko i njihove nemoći da se konstituiraju kao Subjekti, koji bi lako mogli transcendirati takvo stanje, jer bi nosili projekt koji bi bili u stanju realizirati, kao što je to pokazao Lešić bar u ekonomskoj sferi. Oni kao da su nagovijestili slijedeći, Krležin, tip umjetnika.

Krležin Pero Orlić, koji u Pariz dolazi djelomično iz sličnih intelektualnih razloga kao i Cesarićev Matoš, puca na Pariz u noveli Hodorlahomor Veliki (1919.). To je drugačija ideja lika - intelektualca, koji van ne ide zbog materijalnoga (novčanoga) nego umjetničko-kulturnoga razloga (Louvre), nošen imaginarnom himerom. Važno je napomenuti da je on vođen idejom Smisla, Spasa i Svijeta u odnosu na provincijski Zagreb. No kako je razvidno, da bi se kultura konzumirala, potreban je određen materijalni status koji osigurava slobodno vrijeme i biološku (vegetativnu) sređenost, kao i materijalna sredstva za bilo koji umjetnički aktivan odnos, konzumiranje umjetnosti ili umjetnički zanat, pače i feljtonski zapis, a kako to Orlić ne posjeduje, jer je brzo potrošio novčane zalihe, dakle jer to u suvremenom kapitalističkom svijetu nije mogao osigurati, on doživljuje uskratu upravo na duhovno-umjetničkom planu radi kojega je i došao u Pariz - pri čemu ne pomaže ni ironizacija u dubinskom sloju (Europa je himera) pa mu - živeći rastrojstvo na granici sna i ideje samoubojstva - ne ostaje ništa drugo nego da bježeći iz toga suvremenog Moloha gestom pucanja iz pištolja na Pariz signira svoj revolt i očaj, zapravo idealističko-utopijsko rješenje, u biti nemoć jer je Pariz gledao kroz zagrebačke naočale, pa je to pucanj u vlastitu fikciju. No ne obračunavajući se balzakovsko-rastinjakovski s Parizom, to jest s modernom civilizacijom i mondenim zanosom za istočnjačke vrijednosti, koje Krleža ekspresionistično kaotično prezentira, on zapravo izravno aranžira svoju smrt, ne samo kao potencijalnog umjetnika, jer nije svladao tehnike usvajanja zbog koje je došao, intelektualca, jer nije nadvladao uskrate, nego i kao čovjeka koji ne postiže puninu sebstva, jer je psihološki rastrojen i jer je nerealizirano biće u punini "opsega" koje je njegovo biće žudjelo, jer je podsvjesno imalo uvida u potrebe koje valja zadovoljiti kako bi se ostvarilo. On ne može "svladati" Europu jer je u biti ostao provincijalac, pa nije ni shvatio dubinu aporije zbilje i ideala, nego jed- 
DRUŠ. ISTRAŽ. ZAGREB GOD. 20 (2011) BR. $3(113)$

STR. $861-876$

MILANJA, C TIPOVI LIKA ISELJENIKA... nostavno, pljuckajući na sve oko sebe, neprimjerenim sredstvom i metodom "rješava" problem, pa je on pravi tip hrvatskoga kvaziintelektualca, iako je simpatičan u svojoj bespomoćnosti.

Posve je drugačiji tip Filipa Latinovicza, intelektualca i umjetnika. No i on je bipolarno biće, biće aporije. Ona se prepoznaje na nekoliko razina. Filip Latinovicz je pravi lik transcendentalnoga beskućnika u fundamentalnom stanju krize identiteta koga određuju brojne dihotomije. Prva po redu, a ne po važnosti, mogla bi se odrediti kao aporija između Latinovicza kao reprezentanta europske kulturne tradicije, od naobrazbe, teorije do ideja, a u biti je marginalac i autsajder, kao umjetnik, ili drukčije rečeno dihotomija je u opoziciji europskog spram panonskog. Vraćajući se, naime, u svoju rodnu Panoniju, on je i tu stranac i derasine. Iako je autsajder kao umjetnik, a vraćajući se promatra sebe kao nešto prošlodoživljeno (što je utjecaj Prousta), on posjeduje slobodu, kao posvećenost i posebnost, no determinira ga građanski život, to jest njegove norme. Na drugom je mjestu dihotomija između percepcije raspadnute slike svijeta (špenglerovski kraj europske civilizacije) spram relativističke, ali konzistentne, životne filozofije Jože Podravca. Na trećem je mjestu "individualna psihologija" (Adler), a zapravo riječ je o nervnom rastrojstvu i Edipovu kompleksu, u sferi biološkog, spram "kolektivnog nesvjesnog" (Jung) kao htonske, atavističke, divlje, mračne i dijabolične strane. Spram Filipa stoji, naime, njegovo drugo ja, Kiryales, zapravo mehanicističko shvaćanje zbilje. Na četvrtoj, može se reći najvažnijoj, razini pitanje je Filipa kao slikara, umjetnika. I na toj razini on je vrlo složeno biće; on percepira svijet velegrada kaotično, ali o tome i reflektira, teoretizira, što znači da interiorizira, pri čemu je narativna tehnika prustovska, s očitom idejom kako je pravi bitak tek u prošlosti (sjećanja). Kako sjećanje bistri prošlost, a slikarski panoi to kušaju objektivirati, pa se s njegova metaanalitičkoga stajališta svijet zbilje nadaje kao nešto što nije samo po sebi ništa, zato što je on (svijet) predmet perceptivnih stimulusa na koje se reagira. Iza njega, kao i Krleže, u slikarskom smislu stoje Goya, Gross, Račić, Becić, Bosch, Dobrović, Brueghel, što je posebna teorijsko-slikarska linija romana.

Postavlja se pitanje kako Filip doživljuje taj kompleks. Naglašeno je kako zbilju doživljuje kaotično, prevedeno slikarovim očima, znači da je riječ o bojama u kretanju, iza čega nije ništa. To bi se moglo nazvati Filipovom koncepcijom slikarstva, no kako je on psihološki rastrojen, on je "impresionistički" osjetljiv, pri čemu u jasnu likovnost upada sivilo, mrlja. Konzekvencija je toga da Filipovo reflektiranje ima svijest o odvajanju osjetilne kvalitete od predmeta, supstrata; riječ je o apstrakciji, bespredmetnom slikarstvu (Kandinsky, protiv ko- 
DRUŠ. ISTRAŽ. ZAGREB GOD. 20 (2011), BR. $3(113)$

STR. $861-876$

MILANJA, C. TIPOVI LIKA ISELJENIKA... jega je Krleža eksplicite bio). Slijedi, dakle, da je gađenje prema svijetu, u egzistenciji, sukladno likovnom izrazu, grotesknom karikiranju, pa bi se moglo zaključiti da se ne konstituira supstancija prema onomu što se gleda (impresionistički pozitivno), nego prema projekciji duševnih stanja koja su "napunjena" znanjem, strahom, gađenjem. Filip je, dakle, u fundamentalnoj dihotomiji impresionističke ideje slikarstva i ekspresionističke slike svijeta, zbilje, a na psihološkoj je to razini vidljivo u hijazmu psihološko-osobnih slika sjećanja iz intimne sfere, koje su jasne i drage, spram rendgenske snimke apstraktnih i reduciranih generalizacija sadašnje, zbiljske slike svijeta, koje ne odgovaraju primarnoj empiriji nego su zapravo "analističko-mentalistička" montaža (ekspresionističko, subjektivno tumačenje) ili sekundarna empirija.

Međutim, što za Filipa znači slikanje (umjetnost), što je Filip slikar? Filipova umjetnička egzistencija nema podloge, nema uporište u društvu, prema Krležinu shvaćanju suvremenoga slikarstva koje je u krizi (Kriza u slikarstou, 1924.), jer je izgubilo svoj oslonac u reprezentativnim funkcijama društva. Kako prema tome Krleža ima negativan stav, on (i Filip) vraća se Babiću, Dobroviću, što znači da je Filip nesklon napustiti mjeru empirizma (figuralne kompozicije), s intencijom da sinestezijski obuhvati totalitet života, naime i spiritualno i ružno. Kriza Filipova identiteta leži, dakle, u impresionističkoj ideji slikarstva i svijesti da se rastočena (ekspresionistička) slika svijeta ne da impresionistički oslikati. U psihološkoj podlozi kriza identiteta ne očituje se samo u svijesti o nepostojanju u pojavnosti nego "samo" u svijesti koja se sjeća, pa je s jedne strane psihološko-impresionistički motiviran, a s druge, pak, strane društvenim potresima, rasapom povijesne tradicije, odnosom umjetnika i društva, različitih kultura, težnji ka sintezi organske prirode i ljudske povijesti, urbanog i ruralnog, sociologije i psihologije umjetnosti te osobno-genetsko i porodično.

I Cesarić ima lik iseljenika kao intelektualca, pače umjetnika, pjesnika (Matoša). Trubač sa Seine nosi podnaslov "Matoš u Parizu". Pjesma je, doduše, "biografizirana", no upravo zbog toga utemeljenije postavlja nekoliko slojeva: za razliku od Krležina Orlića, Matoš je, prema Cesariću, ispunio zanatsku i kreativnu radoznalost unatoč neprestanoj gladi i siromaštvu, pa mu tjelesno vegetabilno nije predstavljalo zapreku. Prvo, on Seinu imaginira kao Savu, što znači da je, slično, osjeća zavičajnom, to više što je Hrvatska još uvijek kolonijalno pokorena Peštom i/ili Bečom, pa se ideja i realizacija slobode još jače nameće kao sadašnji uvjet života. Pariz može biti sinonim slobode, ali ne "bezostatno", jer mu se (umjetniku, intelektualcu) jezik (hrvatski, dakako) nameće kao zadnje zavičajno istinsko mjesto, koje nije samo gesta utjehe nego i 
DRUŠ. ISTRAŽ. ZAGREB

BR. $3(113)$

STR. $861-876$

MILANJA, C. GOD. 20 (2011) TIPOVI LIKA ISELJENIKA...

književna realizacija bića. To se biće ostvaruje književnim radom, no taj rad, jezična realizacija bića, vraća se Hrvatskoj kao kulturna činjenica koja se, unatoč porobljenosti, ostvarujući se kao biće, potvrđuje njegovo sebstvo, njegovu kulturu, njegovu slobodu. Iz toga slijedi da je književni rad u jeziku i jezikom najviši zalog slobode, jer predstavlja kreaciju i imaginaciju koja radi i proizvodi kulturni konstrukt Hrvatske, a "preko" kulturnoga konstrukta ima ambiciju zbiljske, "činjenične sređenosti", to jest društveno-povijesne realizacije. To je drugačija uloga umjetnika i intelektualca općenito negoli je ona Krležina Orlića i Filipa, što znači da je Cesarićev Matoš transcendirao predmetnost tijela kao tehničke potrošne predručne (Heidegger) robe i postao, za stupanj više, kreativni subjekt koji činom književne, umjetničke, to jest kulturne proizvodnje ostvaruje slobodu shvaćenu u najširem smislu, čak veću nego što je pružaju obične pragmatične (pa i političke) dnevne prakse i opskrbe u svojim (ne)realizacijama.

\section{TIP LIKA ISELJENIKA SVEDENOG NA POLITIČKO-IDEOLOŠKO BIĆE}

Iako bi se moglo reći da su sljedeći likovi stanovite varijante nekih dosadašnjih tipova likova, ipak je temeljno određenje likova kao što je Otto Šoljanove drame Bard i, s druge strane, Bonifačićeva Oskara Juranića iz romana Bit ćete kao bogovi (1950.), može se reći da u stanovitom smislu čine zaseban tip lika. Naime, Šoljanov bi Otto i mogao biti "nastavak" nekog od Krležinih likova, ali je on ovaj put ipak političko-ideološki instrumentaliziran. I Otto, pjesnik, dolazi nakon trogodišnjega boravka u Parizu natrag u svoju metonimijski predočenu komunističku Jugoslaviju, zamijenjenu, opet metonimijski, Kubom. On će na kraju platiti pobunu protiv mehanizma totalitarističkoga stroja i smjelost da se opredijeli za Europu, slobodnu, liberalnu, igrivu i "neozbiljnu". Smjelost za novu mogućnost slobode i kreativne neovisnosti bila je, prema tumačima kulturnih čuvara režima, tako reći unaprijed isključena, jer je već apriori bila uvjetovana planiranom ideološkom heroizacijom pjesnika Revolucije, kakav je Otto bio ranije, pa njegova kvazimajakovština ostaje predestinirajućim bremenom što ga se ne može lako osloboditi; drugo, slobodan način pariškoga života postaje njegova zamka, jer je zapravo u stanovitom smislu nastavak (bar javno zabranjene) domovinske prakse hedonizma, pa mu se on vraća kao osveta; i treće, on čak kao već afirmiran pjesnik u Parizu (pretpostaviti je na francuskom jeziku - što je opet neka vrsta implicitne zabrane, jer je predodređen "slavu stjecati" na hrvatskom jeziku) svoju veličinu ondje stječe "samopodrazumijevajućim" angažmanom različitih službi iz domovine (za koje on, dakako, ne zna), države koja ga je poslala onamo kako bi ga udaljila od skandala 
DRUŠ. ISTRAŽ. ZAGREB GOD. 20 (2011), BR. $3(113)$

STR. $861-876$

MILANJA, C. TIPOVI LIKA ISELJENIKA... zam Vlasti. On tako postaje u neku ruku vlastita zamka/žrtva bivšega "zabranjenog" hedonizma i bivše "dobrovoljne" revolucionarne heroike, koja je zapravo, bar kad je riječ o pjesništvu, također bila samopodrazumijevajuće iznuđena. Na taj način on zapravo poravnava jednako vlastite koliko i državno-ideološke račune, pri čemu mu je Vlast samo "medijatorom". Iz toga je jedini izlazak, ako želi donekle biti sebi dosljedan, čin revolverskoga samoubojstvenoga hica, što on i čini. Ovdje je dakle Otto tip lika žrtve ideološko-partijsko-državno totalitarističke, s jedne strane, te slabe vlastite predvidljivosti političko-ideološkoga "zbivanja" vlastitosti. On je, dakle, i osobna i javna tragedija.

Bonifačićev lik, Juranić, donekle je "obrnuti" tip lika - iako je sličan po "izvodu" - jer ga istom mjerom sustiže vlastita boljševička represijska narav u vrijeme staljinističkih čistki, pa je u tom smislu "realnije" izveden na taj način što ga cinizam "političkog" života "poravnava". U inače umjetnički slabijem romanu Bonifačić podastire realnu toponimiju, pače i stvarne povijesne ličnosti, a riječ je o procesu Dil-Osvald. I Juranić, rođeni Riječanin, u mladosti se priključio komunističkom pokretu, borio se u Španjolskoj, bio zatočen u Dachauu, a poslije rata obnašao je dužnost generalnoga sekretara ministarstva vanjskih poslova u komunističkoj Jugoslaviji, na kojoj je dužnosti uhićen 21. travnja 1947. pod optužbom da je bio špijun strane obavještajne službe u Beču, a da je već 1942. u logoru u Fürthu pristao na suradnju s Gestapoom, te je kao njihov agent uhodio internirce, a 1943. u Dachauu isto, da bi u siječnju 1944. organizirao provokatorsko vodstvo tobožnje antifašističke organizacije te njezino djelovanje usmjerio po uputama Gestapoa. Normalno da je, uz iznuđeno priznanje, uostalom kao partijski zadatak, bio osuđen na smrt. Ovdje bi se moglo reći da se Bonifačić, kao egzilni pisac, osvećuje svojemu liku tako što ga prikazuje najprije kao reprezentanta jugoboljševičkoga tipa orgijanja, gotovo perverzna uživanja u moći nad tuđim životima, dakle kao tipa amoralnog i vulgarnog materijalista, što bi trebalo sinonimizirati komunistički nemoral. To je imalo za posljedicu da Bonifačić vjeruje u Juranićevu krivnju, iz čega je razvidno kako se egzilna literatura posve politički diletantski odnosila prema povijesno stvarnoj zbilji i nije temeljitije proučavala prirodu staljinističkih procesa, pa nam ovaj tip lika i ne može poslužiti kao paradigmatski primjer hrvatske egzilne literature, osim u smislu loše izvedbe.

\section{ZAKLJUČAK}

Iz kratke analize navedenih primjera i svojevrsne tipologije lika iseljenika u domicilnoj (i dijelom egzilnoj) hrvatskoj književvo svojevrsne hipoteze za daljnja razmišljanja, i glede tiponosti 19. i 20. stoljeća nadaju nam se sljedeći zaključci, zapra- 
DRUŠ. ISTRAŽ. ZAGREB GOD. 20 (2011), BR. 3 (113),

STR. $861-876$

MILANJA, C. TIPOVI LIKA ISELJENIKA... logije i glede segmenata kulturne modernizacije Hrvatske $u$ navedenom razdoblju, a dakako i one vječne krležijanske dihotomije Hrvatska - Europa, Subjekt - Objekt, Središte - Margina, prije svega $u$ kulturnom, ali ne samo $u$ tom smislu, nego je riječ i o Moći. Naime, otvara nam se nekoliko problemskih polja; na prvom je mjestu jamačno tipologija "lika iseljenika" kako ga je hrvatska književnost 19. i 20. stoljeća zamislila, kreirala i projicirala. $S$ tim u vezi vidjeli smo da se on može načelno podijeliti $u$ dvije grupe. Jedna je ekonomska, koja je nastojala osigurati bolju i bezbrižniju egzistenciju glede materijalnih uvjeta života, i u biti je jednoplošnija. Ona je, dakako, implicirala i drugačiji odnos prema radu, tehnologiji industrijskog inženjeringa u koji se dotični morao uklopiti da bi zadovoljio funkciju u sklopu tehničke progresije kapitala i njegove akumulacije. U tom su se sloju likovi jednostavno trošili kao materijali koji i nisu namijenjeni za drugačije namjene nego takve. Oni su više-manje tretirani kao potrošna roba.

$\mathrm{Na}$ drugom je mjestu nova procedura dnevnoga života s ritualom radne funkcije (posao) kao i slobodnoga, dokoličarskoga, vremena. Taj je segment radio na društvenoj verzifikaciji i "novom odgoju" pojedinca kao člana drugačije društvene stratifikacije negoli je bila ona u Hrvatskoj, posebno ako su oni živjeli u velikim gradskim aglomeracijama, pa je bila riječ o kulturnoj urbanizaciji. Na trećoj razini, nova tehnička i urbana norma, koja je omogućavala nove elemente za drugačiju kulturaciju, svladavanjem tehničkog i usvajanjem gradskog, nudila je također elemente za "prijelaz" iz stanja lika kao potrošnoga materijala, to jest predmeta, $\mathrm{u}$ stanje subjekta $\mathrm{u}$ kojem se "novi identitet", koji je eo ipso zadan, mogao "pretvarati" u ipsitet i sebstvo, koji je u stanju kartezijanski misliti "svoj položaj" i tako stjecati ontološki status subjekta (novog identiteta). On je trebao zadovoljiti ne samo funkcijske datosti, nametnutosti, koje je vršio najamnim radom, nego i metafizičko opravdanje prisvajanjem etičke i moralne legitimnosti, čime se transcendiralo stanje puke predmetnosti i puke funkcijnosti, a stjecalo i time ontološki opskrbljivalo "novi identitet". Time se tehničko, tehnologijskim usvajanjem i vršenjem funkcije, pretvaralo $\mathrm{u}$ ontološko upravo $\mathrm{u}$ skladu Heideggerove hermeneutičke procedure, a time je ujedno i stanje transcendentalnoga nomada evoluiralo u stanje pronalaska zavičajnosti, mišljeno ne kao puke rodne grude, nego kao pronađene nove zavičajnosti bića. Poseban je i složen tip umjetnika koji je otišao u egzil iz kulturno-umjetničkih potreba, kako bi se opskrbio novim tehnologijama, ali i umjetničkim, i tako, obogaćujući se duhovno, vježbao svoju kreativnost i izrazio vlastite potencijale i puninu bića, osmislio umjetnički i egzistencijalno svoju ličnost. 
Cesarić, D. (2008.), Izabrana djela, Zagreb, SHK, MH.

Frangeš, I. (1974.), Matoš. Vidrić. Krleža, Zagreb, Liber.

Gjalski, Š. (1964.), Janko Borislavić, Zagreb, PSHK, MH.

Hećimović, B. (1976.), 13 hrvatskih dramatičara, Zagreb, Znanje.

Hegel, G. W. F. (1951.), Filozofija povijesti, Zagreb, Kultura.

Horvatić, D. (1993.), Nepostojeći hrvatski pisci, Sisak, MH.

Jelčić, D. (1984.), Matoš, Zagreb, Globus.

Kozarac, J. (1997.), Mrtvi kapitali, Zagreb, SHK, MH.

Kranjčević, S. S. (1958.), Sabrana djela, I, Zagreb, JAZU.

Krleža, M. (1963.), Novele, Zagreb, Zora.

Krleža, M. (1969.), Povratak Filipa Latinovicza, Zagreb, Zora.

Lasić, S. (1982.), Krleža, Zagreb, GZH.

Lasić, S. (1987.), Mladi Krleža i njegovi kritičari, Zagreb, Globus.

Lasić, S. (1989.), Krležologija, I, Zagreb, Globus.

Matoš, A. G. (1973.), Sabrana djela, Zagreb, Mladost.

Nemec, K. (1994.-1998.), Povijest hrvatskog romana, I, II, Zagreb, Znanje.

Novak, V. (1964.), Dva svijeta, Posljednji Stipančići, Zagreb, PSHK.

Preradović, P. (1997.), Izabrana djela, Zagreb, SHK, MH.

Šoljan, A. (1984.), Izabrana djela, I, Zagreb, MH.

Tucić, S. (1969.), Povratak, Zagreb, PSHK, Zora-MH.

Vojnović, I. (1964.), Ekvinocij, Zagreb, PSKH, Zora-MH.

Žmegač, V. (1986.), Krležini evropski obzori, Zagreb.

\section{Immigrant Character Types in Recent Croatian Literature}

Cvjetko MILANJA

Institute of Social Sciences Ivo Pilar, Zagreb

The paper outlines a possible typology of immigrant characters in 19th and 20th century Croatian literature. Since there are almost no similar articles in Croatian literary historiography, the author warns methodologically of two levels and two separate issues - the treatment of these topics in local and exile literature. Generally, there is the type of character of economic provenance - with a hoarding mentality, along with the home nostalgic - as well as the figure of the artist intellectual who emigrates to fulfil his/her cultural needs, and ultimately, the politically and ideologically charged character, which was more in the focus of attention of exile literature.

Keywords: political emigrant, economic-hoarding type, community, individual, intellectual, artist, literature 
DRUŠ. ISTRAŽ. ZAGREB GOD. 20 (2011)

BR. $3(113)$

STR. $861-876$

MILANJA, C.

TIPOVI LIKA ISELJENIKA...

\section{Typologie von Emigrantenfiguren in der jüngeren kroatischen Literatur}

Cvjetko MILANJA

Ivo Pilar-Institut für Gesellschaftswissenschaften, Zagreb

Der Verfasser skizziert in seiner Arbeit eine Typologie von Emigrantenfiguren in der kroatischen Literatur des 19. und 20. Jahrhunderts. Da Untersuchungen über dieses Thema in der kroatischen Literaturwissenschaft so gut wie nicht existieren, begleitet der Verfasser seinen Text mit dem methodologischen Verweis, dass man dabei zwei verschiedenen Ebenen bzw. zwei gesonderten Themen Rechnung tragen müsse: der einheimischen Literatur einerseits und der Exilliteratur andererseits. Grundsätzlich lassen sich drei Typen kroatischer Auswanderer erkennen: 1. der Wirtschaftsemigrant, dem es nur auf die Anhäufung materieller Güter ankommt und der seiner Heimat in Nostalgie verbunden ist; 2 . der Typ des Intellektuellen und Künstlers, der aus kulturellen Bedürfnissen heraus sein Land verlässt, und 3. der Typ des politisch-ideologisch motivierten Emigranten, der überwiegend in der Exilliteratur thematisiert wird.

Schlüsselbegriffe: Politischer Emigrant, Wirtschaftsemigrant, Gemeinschaft, Individuum, Intellektueller, Künstler, Literatur 